\title{
The Educational Innovation Comparison of a Techno teaching Analysis in Primary School between Indonesia and Taiwan
}

\author{
M Y Efendi', S Latief ${ }^{2}$, \& H N Lien ${ }^{3}$ \\ 1,3Department of Education and Human Potentials Development (DEHPD), National Dong Hwa University, \\ Hualien, 97401 Taiwan \\ 2The Institute of Social and Political Science Nurdin Hamzah, Jambi, Indonesia \\ Email: 1yefendi934@gmail.com; 2niniek_yuni@yahoo.com
}

\begin{tabular}{l} 
Article Info \\
\hline Article history: \\
Received March 20, 202 \\
Revised April 20, 2020 \\
Accepted April 21, 2020 \\
\hline Keywords: \\
Indonesia \\
Taiwan \\
Primary School \\
Students' achievement \\
Techno teaching \\
Teacher's competence
\end{tabular}

\begin{abstract}
Education in Indonesia is still far from the quality expected by the Indonesian Government, through the national education curriculum compared to other countries, such as Taiwan. Governments and communities in Taiwan are fully aware that it is very necessary to have a strong commitment to improve and develop the national education system as the key to the success of the country to deliver a quality education. This research aims to respond the relation of teacher teaching experience (TTE) and instructional delivery on teacher's competence (TCC), classroom curriculum (CC), and personal competencies (PC) by examining teachers in the primary schools from Taiwan and Indonesia. This study explores the differences between Taiwan and Indonesia cohort in TCC, CC, PC and correlation between TTE and TCC, CC, PC to bring learners' achievement. The results shown that the TCC, CC, PC are different from Taiwan and Indonesia. Then, TEE is statistically significant on TCC, CC, and PC. Broadly, the formulation of techno teaching in each country is stacking by the Minister of Education, and in the application and its development is the authority of the school in the effort to increase student achievement and achieve the standard of submission that has been established by the Indonesian Government through the ability of educators in the effort to achieve educational objectives in Indonesia, especially elementary school.
\end{abstract}

\section{INTRODUCTION}

Education is the most fundamental and important thing in human life, because through the education of all the potentials brought by humans since it can be developed through the education process. So since people get education then it is the first step to develop and realize all things that are dreamed in every layer of human life. As history engrave the story that human civilization develops since education exists. In parallel the process of education has also progressed very rapidly, both in the form of methods, facilities and targets to be achieved. For this is one of the characteristic and educational techno teaching features in Indonesia. And if an education does not experience and does not cause progress or even causes setbacks, it is not called education. Because education is an integral activity that includes targets, methods and means of forming human beings who are able to interact and adapt with their environment, both internally and externally for better progress. In an effort to improve the quality of education, the Indonesian government has changed its curriculum from 1947 to 2013.

This research aims to review and describe the ability of teachers between two countries namely Indonesia and Taiwan in this case Techno teaching, teacher competency and student achievement, teacher teaching experience (TTE), teacher competence in delivering instruction (TCC), class Curriculum (CC), and personal competence (PC), so as to give an overview about the advantages and disadvantages of each teacher in both countries in implementing the curriculum as a reference to national education system. 
Teachers carry the important responsibility to educate their students and bring students' achievement based on the techno teaching and teacher's competence. Moreover, students' parents put their trust on teacher to contrive their children's experts, talents and inclinations. Consequently, teachers must improve their competence in teaching such as instructional delivery, classroom management, and personal competencies.

Teachers' competencies define in different perspective. Some people mention that the competency of teachers is a series of knowledge, skills and experiences that have been held by someone in carrying out their duties and responsibilities as an implementing education curriculum. (Katane, 2006; Jackson, 1990), and others mention that the competency of teachers consists of six elements that are interconnected with each other that is knowledge, expertise, behavior, value, confidence and motivation that is integrated in teachers as educators. (Gupta, 1999).

Teacher's competencies are linked to students' achievement (Miller et. al., 2019; Sellar, 2014; Hammerness, 2005; Reagen et al, 2002; Rowan, 2002; Day; 1999). Furthermore, teaching competencies consists of three abilities that are to manage a classroom, to deliver instructional, and to have personality (Evertson \& Weinstein, 2013; Knight, 2012; CornelliusWhite, 2000).

The comparative study of the techno teaching, teacher's competence and students' achievement find out the related aspect of educational system in certain country. For this reason, we interest to discuss about the teacher teaching experience (TTE) and instructional delivery on teacher's competencies (TCC), classroom curriculum (CC), and personal competencies (PS) from across country, Taiwan and Indonesia. We limited our study on TTE and TCC, CC, PC of teachers from Taiwan and Indonesia in the primary school. Therefore, the primary research question is to explore the difference and similarities of teacher's competencies (TC) between Taiwan and Indonesia. Secondary research question is to seek the correlation between teacher teaching experiences (TTE) and teacher competencies (TC) to bring students' achievement from Taiwan and Indonesia.

This paper is presented on the basis of a research analysis and a literature review from various relevant sources, therefore considering the limitations of the authors of this paper, constructive input and suggestions are needed for the perfection of this paper. However, the author has made every effort to present this paper so that it is expected to be able to add material, insights and studies of the author about various understanding of the educational systems between Taiwan and Indonesia. The writing of this paper is limited only to discuss the Educational Innovation Comparison of a Techno teaching Analysis in Primary School between Indonesia and Taiwan.

\section{LITERATURE REVIEW}

\section{Indonesia}

\section{Technoteaching of Educational system}

The advancement of technology and the use of Internet network in every activity is one of supporting aspects in improving the quality of education. Therefore, educators should have the capability to use and utilization of technology in every learning activity. The use of technology and the Internet as aids in learning activities known as techno teaching, can help improve student achievement. The use of techno teaching demonstrates the ability of educators in the process of learning activities. The use of techno teaching is done through "stellar units", "dare-devil missions" and other educators ' activities such as creating the look of a learning activity plan, storing documents as a reflection attempt on the learning activities that have been conducted, and the search for other learning reference sources. It can be used directly and in learning activities. (Donald, John \& Maria, 2014). 
Technology can support educational system to increase higher educational quality especially in primary school, and thus technology-based learning and teaching systems have widely been used in some schools supported by Information Communication and Technology (ICT), Facilities and students' assessment or e-learning.

Utilizing the development of science and technology has been carried out in various aspects of life, including educational aspects by conducting educational innovations. Innovation is the use of technology in the learning process such as designing materials with an interesting look and using other additional resources related to the material presented. Therefore, educators should have the ability to use and utilization of technology in every learning activity that is undertaken to improve students ' abilities in the material they convey.

According to Berube and Poellhuber (2005), emphasized that the different teaching methods, the technological and techno-pedagogical skills of teachers must be developed techno-pedagogical skills are defined as the ability to use ICT in a pedagogical context. Few studies have taken into account the means used to properly develop the techno-pedagogical skills of teachers. In addition to, it is still necessary to properly identify the constituent elements of it.

\section{Indonesian curriculum}

The education curriculum used in Indonesia is currently 2013 curriculum, which is a change in the curriculum that has been previously used, namely education Unit level Curriculum, "Kurikulum Tingkat Satuan Pendidikan (KTSP)". The 2013 curriculum is a government effort to improve the quality of education in Indonesia, with an emphasis on the aspects of self-reliance, activity and creativity in teaching learning activities.

The purpose of education is to explore and develop the potential of learners, so that learners have the characters needed by themselves, families, and the community. The character that is intended in educational purposes is such a fear to God Almighty, noble, healthy, knowledgeable, creative, independent, responsible, capable, and so forth.

Based on the regulation Ministry of Education and Cultural Minister of Republic of Indonesia No, 47 year 2008, every Indonesian citizen must follow 9 years of primary education, which is six years in elementary school education or Madrasah Ibtidaiyah and three years of education in junior high school or Madrasah Tsanawiyah. This regulation is a form of government effort to provide opportunities and improve the quality of education in Indonesia.

The establishment of a compulsory education for nine years was designed with the aim that no Indonesian citizen has an education level under junior high school. The Indonesian Government is obliged to learn 9 years of providing education for free that is to advise all tuition fees. Unlike other countries that include legal sanctions against violations of mandatory learning programs for parents who do not submit their children, the government of Indonesia has not sanctioned in the violation of compulsory program for learning 9 years. As in the No Child Left Behind Act of 2001 in the USA to carry out reforms in the education sector.

According to Print (1998), the program must study 9 years which has been proclaimed by the Government of Indonesia, in reality has not walked in accordance with the existing rules, because there are still many elementary schools that require parents to pay tuition fees in various forms such as voluntary donations, book costs and so forth, as well as many children compulsory age of school 9 years who are not attending. In addition, there are still many selection processes for prospective students who will enter the public junior high school, so that many students are not admitted to the public school. This indicates that compulsory education of 9 years has not been fully implemented in Indonesia. 
Educational curriculum is a program or guideline as a reference for the development of education that must be carried out by teachers and students in the process of teaching and learning activities to achieve educational goals. Since Indonesian Independence in 1945, Indonesia has made ten changes to the curriculum. The curriculum changes as a consequence of following the changing needs of the times. Factors influencing changes in the direction of the curriculum in Indonesia are influenced by the political, economic, social, cultural and technological systems and the demands of competitiveness between countries at regional and international levels.

The grass-roots approach is an approach to developing a curriculum designed by teachers and not given by the central government (Print, 1998). The thing that needs to be considered in this approach is increasing teacher competency, because without a teacher who has professional competence, this approach will not work. According to Neil (2010), the most fundamental thing in the curriculum development model is to conduct a diagnosis or analysis of the needs, formulate objectives, choose content or material, organize the materials, conduct a selection of the learning experience, organize learning and conduct restrictions on what is evaluated and how to evaluate.

\section{Teachers' competencies}

Based on law number 14 of 2005 about teachers and lecturers, competence is a set of knowledge, skills and behavior that the teacher has in performing its duties as an educator. The competency of teachers is the ability, skills and behavior of the teacher in the learning process. The competency is the ability to encourage active students in learning activities, designing learning activities, creating a fun and competitive classroom atmosphere, and becoming a role model for students in both behave and behave. Students in learning activities bring the basic knowledge that has been held in the learning process, so teachers must realize that they are instrumental in digging, developing, and improving student skills in the learning process, problem solving, processing information, understanding the learning materials, and developing concepts that are understood by classifying, comparing and adjusting of all aspects and learning processes. Students can then continually plan, control, evaluate, and correct their duties during the learning process. There are three levels of learning process in class. First, invite students to study, which is an effort to build a student's interest in learning and receiving information, it called (Meta) cognitive. Secondly, affective-motivational, it involves students in classroom learning activities so that students are accustomed to planning, organizing and engaging and evaluating their own learning activities. Third is a social process, namely in the learning activities there is a relationship between students and teachers and between students in the classroom and school. So that the students try to improve his ability among friends and use his skills to achieve the learning objectives they do. (Rychen \& Salganick, 2003).

In an effort to reflect and summarize information related to the competence of educators and their correlates with students ' achievements in the focus of different studies, the thought-provoking framework is the cornerstone of advanced research. As outlined above, the foundations used in the study relate to the correlation between teacher competence and student achievement are (Meta) cognitive, motivational affective, and social process.

All activities undertaken in classroom learning activities are geared towards satisfactory student learning outcomes, which are not only cohertively, but in the affective and social process aspects. In other words, the expected learning outcomes are the birth of students who have knowledge and character. Therefore, teachers as educators in the classroom should focus on the three levels of the teaching process that has been outlined, for example, teachers who only focus on achieving learning outcomes in the form of the highest scores achieved by students in their subjects and ignoring other levels will then direct the learning 
process at the achievement of the highest value, so that the teacher in his activity ignores other things such as students, Indigo values and behavioral norms as well as other interaction processes. The teacher focused only on achieving the learning outcomes in numerical form.

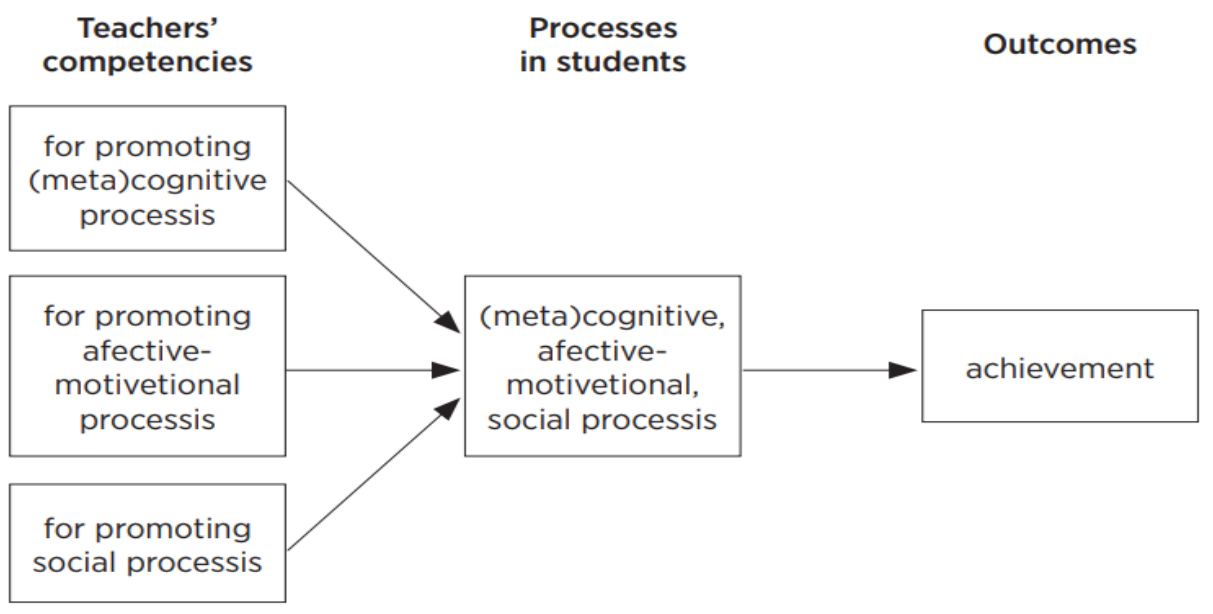

Figure 1. The effects of teacher's competencies on students' achievement

In Figure 1, educators must be fully aware that their competence in the learning process is very influential in the level of achievement of student learning. The form of educator competition based on the above figures in the form of teachers ' ability to improve Meta cognitive, develop attitudes and motivation to learn, and the ability to interact learners (three levels of student achievement), to improve student achievement. Thus, it can be concluded that educators ' competence is the ability to improve student thinking, motivation and learning attitudes, and deep student interactions. Competence is owned by educators not only in the ability of science but also in personality and social. (Rychen \& Salganick, 2003).

Figure above focuses on the relationship between the cognitive and non-cognitive competence of educators in learning activities and improving student achievement in the classroom. These competencies depend heavily on learning strategies, learning methods, classroom creativity, educators ' attitudes and behaviors in the effort to increase student achievement. The literature used in this study relates to the competency of teachers, learning activities, and student achievement.

\section{Taiwan Education}

\section{Technoteaching of Educational system}

Techno teaching is a new idea or a new approach that involves the advancement of science and technology in the learning process. This approach was developed so that educators can design learning by leveraging technological developments and information in learning activities. Techno teaching is also a form of reform in education

Techno Teaching is a basic competency of teachers in conducting learning activities by enhancing creativity in designing learning. Creativity owned by educators is very important in delivering innovation learning activities, because creativity and innovation are two things closely related, so creativity will produce innovation and vice versa. Referring to previous research, innovative learning activities can be divided into seven dimensions, namely idealism, curriculum content, learning resources, facilities and infrastructure in the learning activities, technology and information, learning methods, and assessment. 
In the education system in Taiwan, there are four categories of education, namely primary education, vocational education, higher education, and adult education. The basic education category consists of kindergartens, elementary school education; and the school has a long-established school term in the rules of education in Taiwan. For example, primary schools are pursued for six years and adult education is conducted in formal and non-formal education as an effort to improve the quality of life of the community. Through this education system, it is expected to improve the welfare of the community and complete the illiterate people of Taiwan society.

Taiwan Curriculum

Taiwan education system is of a decentralized nature, meaning that from the central, provincial, district, district and including autonomous regions to the same level. Anyone responsible for implementing education is the state education commission, which is a government professional organization in the field of education development. For education costs available to the central and regional governments with distribution, the allocation of special regions to education is managed by the regions while the central funds are for educational institutions in the ministries.

The curriculum is formulated by a state education commission that is very flexible and varies on the basis of the capabilities and characteristics of the region, city and village and provides flexibility for the region to add a local curriculum. With reference as follows: SD contains 10 different subjects between cities and villages. For rural elementary schools for example: loading agricultural subjects in addition to core subjects, morals, mathematics and Chinese language. As for urban elementary schools, sports subjects are required. Whereas for junior high schools providing 13 subjects including: Moral education, politics, Chinese language, foreign languages and mathematics. Whereas for high school it is adjusted to the wishes of students (tailored to the needs of the community, as well as the conditions of the local institution).

The examination system is examined, for primary and secondary schools to carry out four types of tests namely semester exams, annual exam exams, school final exams and junior high school entrance exams, and these exams are only limited to Chinese language and math subjects. While the high school entrance examination is combined with the junior high school exam. To enter college a national selection exam is conducted with a separation between science and social science.

\section{Teacher`s Competencies}

Teachers carry the important responsibility to educate their students and to bring students' achievement. Moreover, students' parents put their trust on teacher to contrive their children' experts, talents and inclinations (Gupta, 1999). Consequently, teachers must improve their competencies in teaching such as instructional delivery, classroom management, and personal competencies.

Based on Taiwan's educational curriculum, the purpose of education is to improve students ' thinking so that students have a balance between cognitive intelligence and mental health, developing students ' ability to communicate and improve students ' knowledge of life i.e. how to interact, convey opinions, the ability to use technology and so on, to improve student career development for the future, and instill the love of homeland.

Competence of educators in the education curriculum in Taiwan is a set of knowledge and expertise that is owned by educators in achieving educational objectives in the form of pedagogic competence, ability to provide students with experience related to social interactions, cultural differences, critical thinking and skills in using technology, designing learning and developing learning activities to achieve the educational objectives that have been established by the government (Katane, 2006; Gupta, 1999; Jackson, 1990). 
Teacher competencies are linked to students' achievement (Miller et. al., 2019; Sellar, 2014; Hammerness, 2005; Reagen, 2002; Rowan, 2002; Day; 1999). Furthermore, teaching competencies consists of three abilities that are to manage a classroom, to deliver instructional, and to have personality (Evertson \& Weinstein, 2013; Knight, 2012; Cornellius -White, 2000). Therefore, the primary research question is to explore differentiates and similarities of teacher competencies (TC) from Taiwan and Indonesia. Secondary research question is to seek the correlation between teacher teaching experiences (TTE) and teacher competencies (TC) to bring students achievement from Taiwan and Indonesia.

\section{RESEARCH METHOD \\ Sample}

The cross-country exploratory study was conducted in two selected primary school teachers' in Taiwan and Indonesia. This study employs a listing of teacher competencies that sources from educational scholars.

The Taiwan cohort includes 213 primary school teachers`from Quangfu, Hualien, Yilan Taipei and Zhongli district on a mix of graduated level. From 213 primary school teachers, $61.03 \%$ were females. The Indonesia cluster involves 209 teachers from primary school in Grobogan, Semarang, Demak, and Pati, Central Java on a differentiated fi level study. Of the 209 primary teacher school in Grobongan, 43.5\% were female. The data were collected during September to December 2019.

\section{Instruments}

The authors provided a questionnaire to assess the correlation of teaching experience (TTE) and teacher instructional delivery to bring learners achievement. The questionnaire measured consists of Instructional delivery on teacher competencies (TC), classroom curriculum (CC) and personal competencies (PC), and teacher teaching experience (TTE). We used a checklist for answer the teachers' competencies using Likert' scale with five choices answered and scored: $1=$ strongly disagree; 2 = Disagree; $3=$ Neutral; $4=$ Agree and 5 = strongly agree. Table 2 details the measures used across the study.

Table 1. Teachers competencies questionnaires (TC) and Teaching experiences (TTE)

\begin{tabular}{|c|c|c|}
\hline \multirow{2}{*}{$\begin{array}{l}\text { Construct } \\
\text { Instructional delivery: }\end{array}$} & Items & Details \\
\hline & & five choices answered and scored: \\
\hline a. Teachers' competencies (TCC) & 10 & 1 = Strongly Disagree, \\
\hline b. Classroom Curriculum (CC) & & $2=$ Disagree \\
\hline c. Personal competencies (PC) & 10 & $\begin{array}{c}3=\text { Neutral } \\
4=\text { Agree }\end{array}$ \\
\hline & 10 & $\begin{array}{l}5=\text { Strongly Agree } \\
\text { Always }=5 .\end{array}$ \\
\hline Teachers teaching experience (TTE): & & \\
\hline a. Gender & 2 & $1=$ Male 2 = Female \\
\hline b. Year of teaching & 4 & $\begin{array}{l}1=\text { less than } 5 \text { years; } \\
2=\text { between } 5 \text { to } 10 \text { years; } \\
3=\text { between } 10 \text { to } 15 \text { years; } \\
4 \quad=\text { more than } 15 \text { Year }\end{array}$ \\
\hline
\end{tabular}

\section{Data Analysis}

The data were analyzed with statistic descriptive to explore the differences of teachers teaching experience (TTE) and Instructional delivery (TCC, CC, and PC), and generated the hypothesis. 


\section{RESULTS AND DISCUSSION}

\section{Studies related to teacher perceptions of professional role and innovating teaching}

The focus of this research is to exam the relationship between the competence of educators and the innovation with the use of technology in learning as an effort to increase student achievement. In collecting data on this research, researchers use questionnaires to research respondents, i.e. educators in elementary schools.

Through the results of a questionnaire that researchers do there are indications that between the communication ability and the use of techno teaching has a very close correlation in the relationship between the competence of educators and achievement of students. The use of techno-teaching in learning activities is also applied in Indonesia, but in the implementation there are differences of competency between educators in Taiwan and Indonesia.

\section{Technoteaching of Educational system}

The scientific literature makes it possible to identify the techno teaching, teacher's competencies and students' achievement, teacher teaching experience (TTE) and instructional delivery on teacher's competence (TCC), classroom curriculum (CC), and personal competence (PC), developed by Mishra \& Koehler (2006), as directly linked to techno-pedagogical skills.

According to Karsenti (2018), this model and its current derivatives. Those most often used in studies that call on information and communications technology in 2009. This model refers to the relationship among disciplinary, pedagogical, and technological content, and has earned a significant place in conventions for education professionals as well as teachers wishing to integrate technology in their teaching. There is an abundance of scientific literature based on this framework, which examined the elements that teachers must know to integrate technology into their practices and how it might impact the subject matter to be taught.

\section{Overview of Indonesia and Taiwan Curriculum}

\section{Indonesia Curriculum}

Educational curriculum in Indonesia based on the Indonesian philosophy, namely Pancasila, and fixed with the highest of Indonesia constitution 1945. Furthermore, the Act of National Education System No. 20, 2003 explains the educational goals that should ensure equal opportunity, improvement of quality, and relevance and efficiency in management to meet various challenges of local, national, and global lives; therefore, it is to develop the potential of learners, to become human beings who have spiritual intelligence (fear of the Almighty God), Emotional intelligence (noble morality, such as honest accountability, responsibility), Intellectual intelligence (science), Motor intelligence (creative, capable, independent), and love of homeland required by themselves as individuals, and in social life both locally, regionally, and internationally.

Based on the AoNes No.20, 2003, the curriculum are carried out an education system the 2004 curriculum, the 2006 curriculum-called "education unit level curriculum" in the local language is called Kurikulum Tingkat Satuan Pendidikan (KTSP), and the 2013 curriculum. Each curriculum has a similar purpose in education. The main purpose of the curriculums is to develop the power of knowledge to overcome the global market demands, to set up the character building, and to enhance the religious values.

The 2013 curriculum is implemented in 2015/2016 academic year. This curriculum leads education process to use the information and technology (IT-base) innovation in learning process. Then, this curriculum gives an opportunity to students in the senior secondary schools to learn another subject from the other studies programs (MNEC, 2012). 
To sum up, the educational curriculum in Taiwan and Indonesia are have similar purposes to bring the learners achievement in order to face the challenge and competition of local, national and global lives. Therefore, teachers should be able to generate the curriculum in learning.

\section{Taiwan Curriculum}

The curriculum is a reference or instruction in conducting learning activities (Sukmadinata, 2008). Through the curriculum, educators can design their learning activities in accordance with the instructional and national education objectives. The basic education curriculum in Taiwan is based on thorough education. The purpose of education in Taiwan formulated through the curriculum emphasizes the increased ability of students to live their lives and to face the challenges of the future. So in the learning activities, educators should have the ability to develop knowledge that is possessed by real action. Competency dimension in learning activities in the form of spontaneity, interaction and communication, and social participation.

These three dimensions can be described as follows: spontaneity emphasized that learners should be capable of self-management and improve their bodies, and Communication and interaction stress that the learners have the ability to communicate and interact by leveraging existing knowledge and technology, thereby creating a healthy and enjoyable communication. Lastly, Social participation directs the learner can accept and appreciate cultural, religious, and social background differences, thereby creating a conducive environment and interaction to improve the quality of life of society.

Teacher's competencies

Teachers have a responsibility towards leaning process and realize the purpose of learning and the learners' background. Furthermore, they have a power to bring students into their future life. Some duties on their hands, for example: students` achievement, school demands, parents hope, and curriculum requirements. So, become a teacher is not easy, they must have ability "to read the student".

Learners have differentiated in ability and ways of learning. There are two categories of learners, the brightness and dull (Holt, 1982). Table 1 describes the differences between the brightness and dull student.

Table 2. The differences between bright and dull students

\begin{tabular}{|c|c|c|}
\hline The dimension of views & Bright students & Dull students \\
\hline Life and reality & $\begin{array}{l}\text { Enormous curious, there is no } \\
\text { wall between himself and } \\
\text { world, keep trying until it can } \\
\text { be }\end{array}$ & $\begin{array}{l}\text { Far less curious, easily to give } \\
\text { up }\end{array}$ \\
\hline $\begin{array}{l}\text { Handle the unexpected } \\
\text { situation }\end{array}$ & $\begin{array}{l}\text { Patient, tolerate with failing, } \\
\text { keep trying until gets the } \\
\text { answer, kept secret how to } \\
\text { solve the problem he has } \\
\text { struggled with, because he } \\
\text { doesn't want people cheated } \\
\text { out from his self }\end{array}$ & $\begin{array}{l}\text { Cannot stand in the situation, } \\
\text { need answered from others. }\end{array}$ \\
\hline Behave in the difficult tasks & $\begin{array}{l}\text { Willing go ahead on the basis, } \\
\text { read more and more, sensible, } \\
\text { reasonable, trustworthy place }\end{array}$ & $\begin{array}{l}\text { Willing go ahead when they } \\
\text { interested in it, senseless, } \\
\text { unpredictable, treacherous } \\
\text { (untrue) }\end{array}$ \\
\hline
\end{tabular}

Source: Holt (1982). 
Table 1 shows the differences between brightness and dull students; both student performance is inevitable in learning process. Therefore, teachers should improve and explore their competencies to overcome mix students`ability in classroom.

The core of teacher competencies are to plan, to assess, to communicate effectively and to manage behavior in learning process (Books et.al, 2004:10) A teacher should have these competencies to meld in the classroom because the classroom consists of attending multifarious element that need to be managed for obtaining the learning purposes. For example, learners' features are difference in tends, social culture and similar needs. Regarding the classroom figures, teacher should understand the classroom figures, such as classroom have same subjects, same environment, and same instruction approach (Tomlinsson, 2001). Therefore, Teachers demanded to have cognitive, intellectual, personal, moral and emotional competencies to bring learners achievement (Murniati, 2007; Sudjana, 2002; Soedarminto, 1991).

Westcott and Harris in Books et.al (2004:31) explain that teaching is not only limited to what problems are being taught, how to develop learning resources, or how to invite students to learn or revolve around learning material problems but also related to how to create a learning space that is interesting and enjoyable, and to get the best value at the end of learning. Barlow (1995) explained that the ability of teachers to do their responsibility in learning appropriately called competencies.

In sum, teachers' competencies means the ability of teachers to apply the curriculum demands fixed the instructional goal, learners' background and classroom features appropriately. The competencies are instructional delivery that consists of teacher competencies (TCC), classroom curriculum (CC), and personal competencies (PC).

\section{Hypothesis}

We hypotheses that there are differences between Instructional delivery competences from Taiwan and Indonesia, and there is correlation between TTE and Instructional delivery to bring learners achievement from Taiwan ad Indonesia.

\section{The differences TCC, CC, and PC from Taiwan and Indonesia}

The results indicate that the differences of TCC, CC, and PC of both countries, Taiwan and Indonesia. The results of test homogeneity shown differences, because $p$ value less than 0.05. The differences of TCC, CC, PC from Taiwan and Indonesia are statistically significant with $\alpha=.000$ for TCC, $\alpha=.001$ for CC, and $\alpha=.012$ respectively. Table 3 displays the results of homogeneity of variance from Taiwan and Indonesia. In sum, there are differences between TCC, CC, and PC from across country.

Table 3. Test of Homogeneity of TCC, CC, and PC

\begin{tabular}{cl}
\hline Dimensions & Sig. \\
\hline Mean_TCC & .000 \\
Mean_CC & .001 \\
Mean_PC & .012 \\
\hline
\end{tabular}

\section{The correlation between TTE and TCC, CC, PC across country}

Based on ANOVA, the $\mathrm{p}$ value less than 0.05 that means the data not homogenate. The correlation between TTE and TCC, CC and PC from Taiwan and Indonesia are statistically significant a for TCC, CC, and PC in lines .121; .118 and .039. Table 4 describes ANNOVA of 
the results of TCC, CC, and PC from Taiwan and Indonesia. It concludes that TTE and TCC, CC, PC of teacher from Taiwan and Indonesia similar to bring learner achievement.

Table 4. ANNOVA of the correlation between TTE and TCC, CC, and PC from Taiwan and Indonesia

\begin{tabular}{lll}
\hline Dimensions & & Sig. \\
\hline Mean_TCC & Between Groups & \\
& Within Groups & \\
& Total & \\
& Between Groups &, 118 \\
Mean_CC & Within Groups & \\
& Total & \\
& Between Groups &, 039 \\
Mean_PC & Within Groups & \\
& Total & \\
\hline
\end{tabular}

Related the comparison between TTE and TCC, CC, PC from Taiwan and Indonesia, the ANOVA identifies the statistically significant differences. Table 5 provides the summary of study hypotheses and findings.

Table 5. The summary of research hypotheses and findings

\begin{tabular}{|c|c|c|}
\hline Hypotheses & Results & Findings \\
\hline $\begin{array}{l}\text { There are differences of TCC, CC, and PC across } \\
\text { the country. }\end{array}$ & Supported & $\begin{array}{l}\text { The TCC, CC. PC of teachers } \\
\text { from Taiwan and Indonesia are } \\
\text { statistically significant } \\
\text { differences with } a=.000 \text { for } \\
\text { TCC, } a=.001 \text { for CC, and } a= \\
.012 \text { respectively. }\end{array}$ \\
\hline $\begin{array}{l}\text { The year of teaching (TTE) influences TCC, CC } \\
\text { and PC from teacher in Taiwan and Indonesia } \\
\text { to bring learners achievement. }\end{array}$ & Supported & $\begin{array}{l}\text { The year of teaching or Teacher } \\
\text { teaching experience (TTE) are } \\
\text { associated with TCC, CC, and } \\
\text { PC to bring learners } \\
\text { achievement. }\end{array}$ \\
\hline $\begin{array}{l}\text { The teachers' gender promotes the TCC, CC, } \\
\text { and PC from both countries. }\end{array}$ & Not supported & $\begin{array}{l}\text { Gender is not statistically } \\
\text { significant effect on Taiwan and } \\
\text { Indonesia teachers' cohort in } \\
\text { TCC, CC, and PC to bring } \\
\text { learners' achievement. The } \\
\text { ANNOVA results } a=.926 \text { for } \\
\text { TCC, } a=.182 \text { for CC, and } \alpha= \\
.171 \text { respectively }\end{array}$ \\
\hline
\end{tabular}

The ability to design curriculum in instructional material or instructional delivery is the primary demanded for teacher to bring learners achievement. Instructional delivery consists of TCC, CC, and PC. The three competencies based on the survey are statistically significant differences on across country. For Taiwan and Indonesia cohorts, the Instructional delivery is positively related to bring learner achievement.

The hypotheses of this study are around the differences of TCC, CC, and PC of teacher in Taiwan and Indonesia in learning and achievement. The literature above led this study to hypothesize that three competencies (TCC, CC, and PC) contribute primarily for learner to obtain theirs' achievement. It seems that the TCC, CC, and PC has greater influenced to obtain the purpose of instructional goal and brings learners achievement for Taiwan and 
Indonesia cohorts. Besides, the TTE is also teachers to grow their competencies in wrapping curriculum in terms TCC, CC, and PC across country.

\section{CONCLUSION}

Teacher takes responsibility to obtain the curriculum to address the lesson plan for bringing learners achievement. It means that teachers' competencies development is essential component of applying and deploying curriculum in order to bring learners achievement. Based on the results and discussion above, TCC, CC, PC has strongly influenced in learning process and achievement. From two countries, Taiwan and Indonesia highlight the benefit of three components (TCC, CC, and PC) for teacher to help their students in learning and achievement. Furthermore, TTE also contributes in TCC, CC and PC of teachers.

From the results of the study and discussion of curriculum comparisons between Indonesia and Taiwan are incude in countries, namely: It can be concluded that, from two countries the educational system is a combination of decentralization and centralization. Each country's curriculum is prepared by the ministry of education, then the school is given the authority to develop curriculum or add local curriculum in accordance with the conditions of their respective regions and student requests.

From the results of the research, the researchers concluded that the competence of educators as a form of professionalism of work and commitment in conducting the teaching by utilizing technological development (techno teaching) is closely related to the ability of teacher innovation in learning activities.

To provide future opportunities for students, the curriculum system should be more flexible and regional to include a local curriculum that is 'creative' according to the conditions of each region, such as the local curriculum in agriculture, fisheries, plantations, technology, etc., not only limited curriculums such as local languages or foreign languages that have been raised so far that they have no effect on employment and provide no guarantee for life. Students work after graduating from school.

This, the author came up, because it turns out that these three countries are quite successful with the local curriculum they choose in the form of agriculture, fisheries and industrial technology, etc., this is evidenced by the many industrial crafts that are home industry in these three countries, so in turn will have implications for the country's economic growth and the welfare of its people is increasing.

\section{REFERENCES}

Barlow. (1995). Supervision and teacher: A private cold war. New York: Berkeley. Mc Cutchan.

Berube, B., \& Poelhuber, B. (2005). Un referential de competences technopedagogies destine au personnel enseignant du reseau collegial. College de Rosemont.

Brooks, V., Abbott. I., \& Bills. L. (2004). Preparing to teach in secondary schools: A student teacher's guide to professional issues in secondary schools. England: Open University Press.

Cornellius-White. J. (2007). Learner-centered teacher-students` relationships are effective: A meta-analysis. Review of educational research, 77(1), 113-143.

Day. C. (1999). Developing teachers: The challenges of lifelong learning. London: Psychology Press.

Departemen Pendidikan Nasional Republik Indonesia. Undang-undang Republik Indonesia Nomor 20 Tahun 2003 tentang Sistem Pendidikan Nasional. Jakarta: 2003.

Donald J. Leu, John and Maria Neag. (2014). Endowed chair in literacy and technology. University of United Kingdom. 
Evertson, C. M., \& Weinstein, C. S. (2013). Handbook of classroom management: Research practice and contemporary issues. New York: Routledge.

Gadjos. O. Judith. (2016). Teacher's professional development on problem solving: Theory and practice for teachers and teacher educators. Taipei: Sense Publishers.

Gupta. K. 1999. A practical guide for need assessment. San Fransisco: John Wiley \&Sons. Inc.

Hammerness.K., Darling, L., Brandsford, J., Berliner, D., Cochram.M., Mc. Donald, M., \& Zeichner.K. (2005). How Teachers learn and develop. In L. Darling-Hammond \& J. Bransford (Eds), Preparing teachers for a changing world: What teachers should learn and be able to do (pp.358-389). San Farnsisco: John Wiley \& Sons.

Holt, J. (1982). How Children fail?. New York: Penguin Education.

Jackson, P. W. (1990). Life in classrooms. New York: Teacher College Press.

Katane, I. (2006). Teacher competence and further education as priorities for sustainable development of rural school in Latvia. Journal of Teacher Education and Training, 6, 41-59.

Knight. J. (2012). High impact instruction: A framework of great teaching. Thousand Oaks: Corwin Press.

Marlow-Ferguson, R. (Ed.). (2002). World education encyclopedia: A survey of educational systems worldwide, Vol. 1 (2nd ed.). Farmington Hills, MI: Gale Group.

Mishra, P., \& Koehler, M,J. (2006). Technological pedagogical content knowledge: A new framework for teacher kowledge. Teachers college record 108, 6, 1017-1054.

Murniati. N.A.N. (2007). Sistem pengelolaan pendidikan di sekolah. Semarang: IKIP PGRI.

Miller. A., Gore.J., Wallington. C., Harris. J., Rodriguea.P.E., \& Smith. M. (2019). Improving student outcomes for a luster randomized controlled trial of quality teaching Rounds. International Journal of Education Research, 98, 146-158.

Ministry of Education. (2014). Curriculum guidelines of 12-year basic education. Taiwan: MoE.

Neil, G.O. 2010. Program design: Overview of curriculum models. Fingal: UCD Teaching.

Nur. 2010. Potret pendidikan di Jepang sebagai konsep pencerahan pendidikan di Indonesia. Jurnal MEDTEK, 2(1).

Peraturan menteri pendidikan nasional nomor 70 Tahun 2013 tentang kerangka dasar dan struktur kurikulum sekolah menengah kejuruan/madrasah aliyah kejuruan.

Peraturan menteri pendidikan dan kebudayaan nomor 47 Tahun 2008 tentang wajib belajar.

Print, M. (1998). Curriculum development and design. Sydney: Allen \&Unwin Oliva.

Peter. F. (1992). Developing the Curriculum 3rd ed. New York Harpers Collins Publisher.

Reagen. T., Case. C., \& Brubachar, J. (2000). Becoming a reflective educator: How to build a culture of inquiry in the schools (2nd ed.). California: Corwin Press.

Rowan. B. (2002). Teachers' work and instructional management. In. Hoy-Wayne. K., \& Miskel-Cecil. G. Theory and Research in Educational Administration. Connecticut: IAP (International Age Publication).

Rychen, D. S. \& Salganik, L. H. (2003). Key competencies for a successful life and a wellfunctioning society. Gottingen, Germany: Hogrefe \& Huber.

Sellar. M. (2014). Reflective practice for teachers. London: Sage Publication.

Soedarminto. (1991). Pengembangan kurikulum dan bahan belajar. Jakarta: Karumika.

Sudjana. N. (2002). Dasar-dasar proses belajar mengajar. Bandung: Sinarbaru Algesindo.

Sukmadinata, N. S. (2008). Pengembangan kurikulum: Teori dan praktek. Bandung: Remaja Rosdakarya.

Tomlinsson, C. A. (2001). How to differentiate instruction in mixed-ability classrooms (2nd Ed.). USA: ASCD

Wahyudin, D. (2016). Manajemen kurikulum dalam pendidikan profesi guru (Studi kasus di Universitas Pendidikan Indonesia). Jurnal Kependidikan, 46 (2), 21. 
Studies in Learning and Teaching (SiLeT)

Vol.1, No.1, April 2020, pp. 27-40

ISSN: $2722-1857$

\section{Corresponding Author:}

Mochamad Yusuf Efendi

Department of Education and Human Potentials Development (DEHPD), National Dong Hwa University, Hualien, 97401 Taiwan

Email: yefendi934@gmail.com 